\title{
International Collaboration on Offshore Wind Energy Under IEA Annex XXIII
}

Conference Paper NREL/CP-500-38748

November 2005

W. Musial and S. Butterfield

National Renewable Energy Laboratory

J. Lemming

RIS $\varnothing$ National Laboratory

Presented at the 2005 Copenhagen Offshore Wind

Energy Meeting

Copenhagen, Denmark

October 26-28, 2005
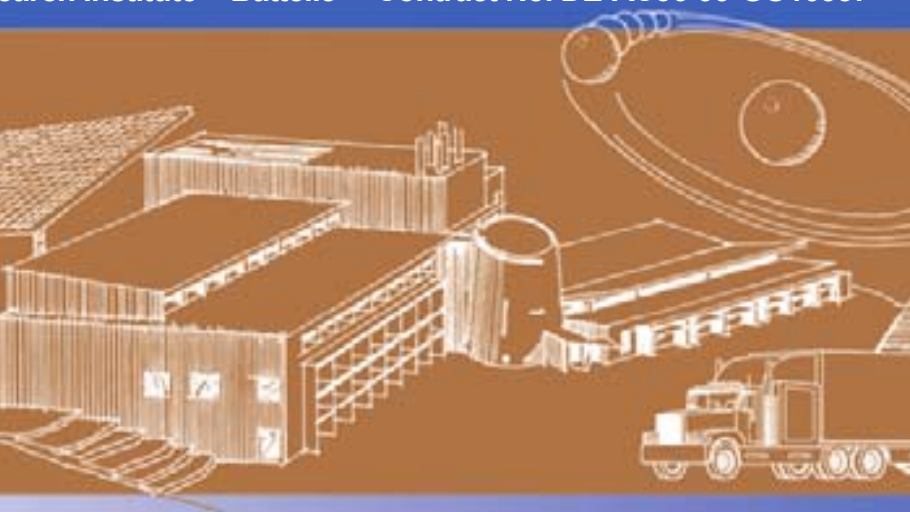


\section{NOTICE}

The submitted manuscript has been offered by an employee of the Midwest Research Institute (MRI), a contractor of the US Government under Contract No. DE-AC36-99G010337. Accordingly, the US Government and MRI retain a nonexclusive royalty-free license to publish or reproduce the published form of this contribution, or allow others to do so, for US Government purposes.

This report was prepared as an account of work sponsored by an agency of the United States government. Neither the United States government nor any agency thereof, nor any of their employees, makes any warranty, express or implied, or assumes any legal liability or responsibility for the accuracy, completeness, or usefulness of any information, apparatus, product, or process disclosed, or represents that its use would not infringe privately owned rights. Reference herein to any specific commercial product, process, or service by trade name, trademark, manufacturer, or otherwise does not necessarily constitute or imply its endorsement, recommendation, or favoring by the United States government or any agency thereof. The views and opinions of authors expressed herein do not necessarily state or reflect those of the United States government or any agency thereof.

Available electronically at http://www.osti.gov/bridge

Available for a processing fee to U.S. Department of Energy and its contractors, in paper, from:

U.S. Department of Energy

Office of Scientific and Technical Information

P.O. Box 62

Oak Ridge, TN 37831-0062

phone: 865.576.8401

fax: 865.576 .5728

email: mailto:reports@adonis.osti.gov

Available for sale to the public, in paper, from:

U.S. Department of Commerce

National Technical Information Service

5285 Port Royal Road

Springfield, VA 22161

phone: 800.553 .6847

fax: 703.605.6900

email: orders@ntis.fedworld.gov

online ordering: http://www.ntis.gov/ordering.htm 


\title{
INTERNATIONAL COLLABORATION ON OFFSHORE WIND ENERGY UNDER IEA ANNEX XXIII
}

\author{
By \\ Walt Musial \\ Sandy Butterfield \\ National Renewable Energy Laboratory \\ Golden, CO USA \\ Jørgen Lemming \\ RISØ National Laboratory \\ Roskilde, Denmark
}

\section{INTRODUCTION}

In 2004, the worldwide installed capacity of grid-connected wind power exceeded $50 \mathrm{GW}$, corresponding to an investment of approximately $€ 50$ billion [1]. Most of the development thus far has taken place on land-based sites, but future development will involve an increasing offshore fraction. At the end of 2004, the total installed capacity of offshore wind energy was $610 \mathrm{MW}$ with all of the current installations in shallow water less than a 20-m depth [2].

Offshore wind holds great promise for expanding wind generation capacity. In Europe, the amount of space available for offshore wind turbines is many times larger than onshore. The potential for wind energy is therefore also considerably greater. As such, plans to expand offshore wind in Europe are well underway, especially in countries such as Denmark, the United Kingdom, and Germany. In the U.S., there have not yet been any offshore wind installations, but two significant projects with a combined capacity of nearly $600 \mathrm{MW}$ have already been proposed and are now in the permitting process.

Existing projects in Europe have proven to be valuable in demonstrating offshore wind energy on a large scale and have gained important technical experience that will be applied to the generation of offshore wind turbines. Not all the experience gained has been positive. The costs of offshore projects have exceeded projections in some cases by underestimating the cost of unanticipated early repairs and presuming onshore accessibility and reliability statistics will hold true for offshore. Increasingly, designers of offshore wind turbines will have to adjust designs to accommodate the unique offshore conditions.

Along with these technical challenges, developers of offshore wind projects are required to analyze environmental conditions of the specific site. The range of analyses involves submitting permit applications, conducting baseline data collection, preparing environmental impact assessments, and conducting pre- and post construction monitoring studies. The methodologies to carry out these analyses are varied in scope, timeframe, and funding, depending on the national regulatory requirements and location.

There is a recognized need to compile credible ecological data for a variety of offshore sites and explore how the existing, site-specific data can be used to facilitate streamlined planning and approval processes. Environmental and regulatory issues are currently a significant obstacle to 
offshore deployment and will increasingly become a more important factor as the technology matures and greater numbers of deployments are proposed.

Future offshore technology will progress to allow access to deeper waters, which will benefit coastal nations with less shallow seas such as Ireland, Spain, Italy, and Portugal. Outside the European Union, China and the United States have the highest potential, followed by Brazil and Japan [3]. In the United States, preliminary estimates of offshore wind resources indicate immense areas of Class 5, 6, and some Class 7 winds (USDOE wind classes) at distances from 5 nautical miles $(\mathrm{nm})$ offshore to $50 \mathrm{~nm}$ offshore [4,5]. These estimates indicate that for the U.S., there are over $900 \mathrm{GW}$ of offshore wind resource in deeper waters (30-900 m) compared to less than $100 \mathrm{GW}$ in shallow water $(0-30 \mathrm{~m})$, and some shallow water sites might be too close to land for public acceptance. In the U.S. where the burden of electric transmission is great, offshore wind could supply electricity with relatively small demand on the transmission grid. Opening these vast windy areas of deep-water ocean for electric power generation will require new technologies to be developed.

An international collaboration through the International Energy Agency (IEA) is an efficient forum from which to advance the technical and environmental experiences collected from existing projects, as well as the research necessary to advance future technology for deep-water wind energy technology. This free exchange of information and experience will help the offshore wind industry proliferate.

\section{DESCRIPTION OF ANNEX XXIII}

In May 2004, the Executive Committee of the International Energy Agency's Implementing Agreement for Co-operation in the Research, Development, and Deployment of Wind Energy Systems unanimously approved Annex XXIII, Offshore Wind Energy Technology and Deployment. The objective of this annex is to conduct R\&D activities of common interest to countries interested in offshore wind energy development that will reduce costs and uncertainties. This annex is comprised of two subtasks. Subtask 1, to be managed by RIS $\varnothing$ National Laboratory, in Denmark, will focus on critical deployment issues associated with current offshore experience. Subtask 2, to be managed by the National Renewable Energy Laboratory, in the U.S., will focus on far-term issues associated with deployment in deeper water. Figure 1 illustrates the general division between subtasks 1 and 2 within the Annex.

A detailed list of possible topics for collaboration were identified at a Technical Experts Meeting held in Denmark in March 2004, and are listed in the Annex document as a starting point for collaboration. The list was prioritized based on the joint interests of the participants and the appropriateness of the topic for sharing information, and was reduced to four research areas listed below. 


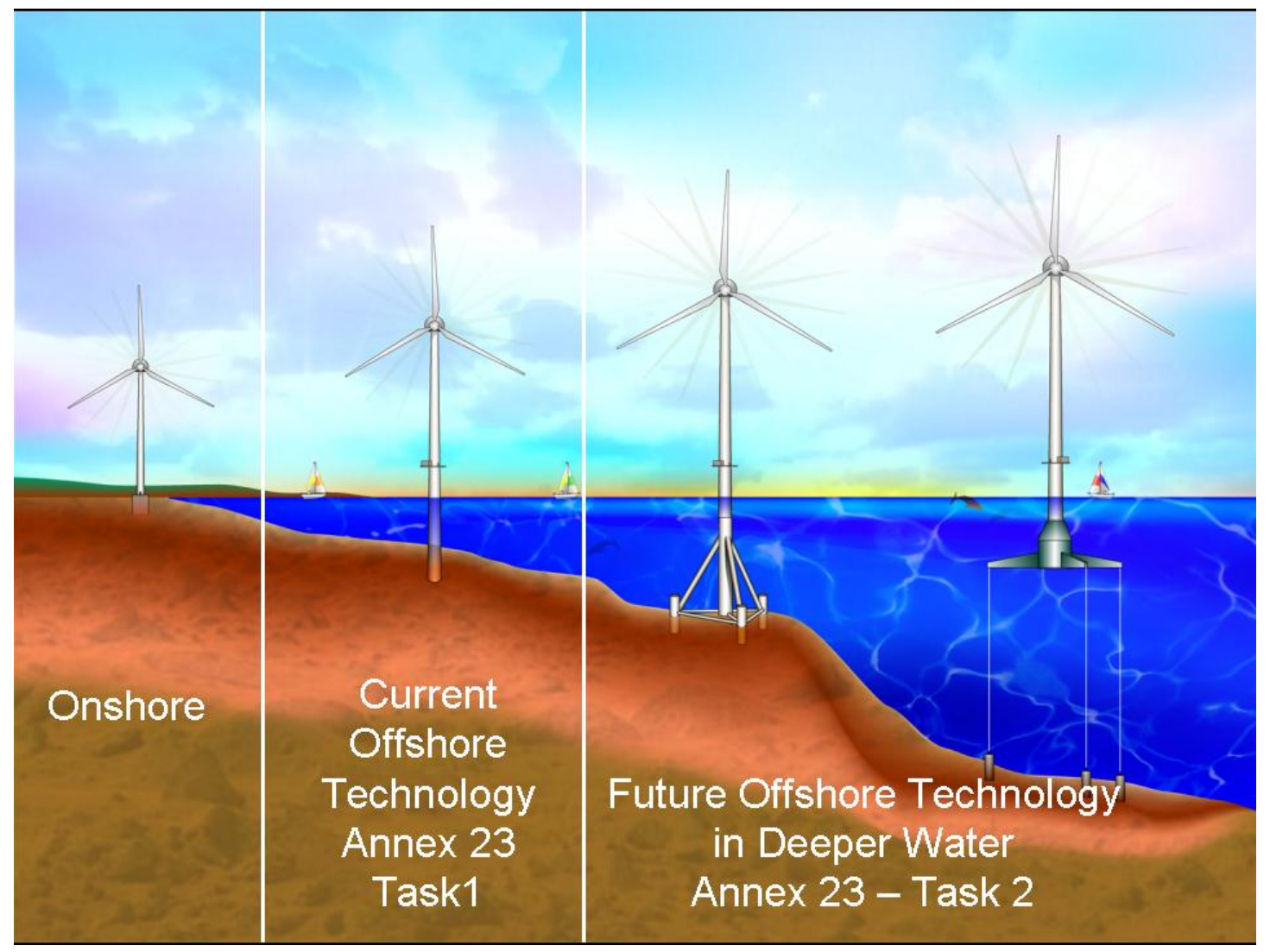

Figure 1 - IEA Annex XXIII Technology Subtasks

Research Area 1: Ecological Issues and Regulations

Research Area 2: Electric System Integration

Research Area 3: External Conditions, Layouts and Design of Offshore Wind Farms. Research Area 4: Modeling Needs for Offshore Substructures (including deepwater floating systems)

Research Areas 1 through 3 are being conducted under Subtask 1. Research Area 4 is being conducted under Subtask 2 as shown in Figure 2.

The United States and Denmark provided in-kind support from NREL and RISØ, respectively, which acted as operating agents during the first year (May 2004 - April 2005) without collecting funds from the Annex members. However, the planned budget in U.S. dollars is approximately $\$ 50,000$ per year, which will be paid for equally among the number of countries who join the Annex (e.g., if eight countries join, the cost in U.S. dollars will be $\$ 6,250$ per country per year). Each country may have several participating organizations for a single membership fee, with the hope that more organizations will lead to more robust results. It will be the responsibility of each country to determine how this cost of membership is distributed among the individual organizations. It is expected that the annex will continue for a period of at least three years. 


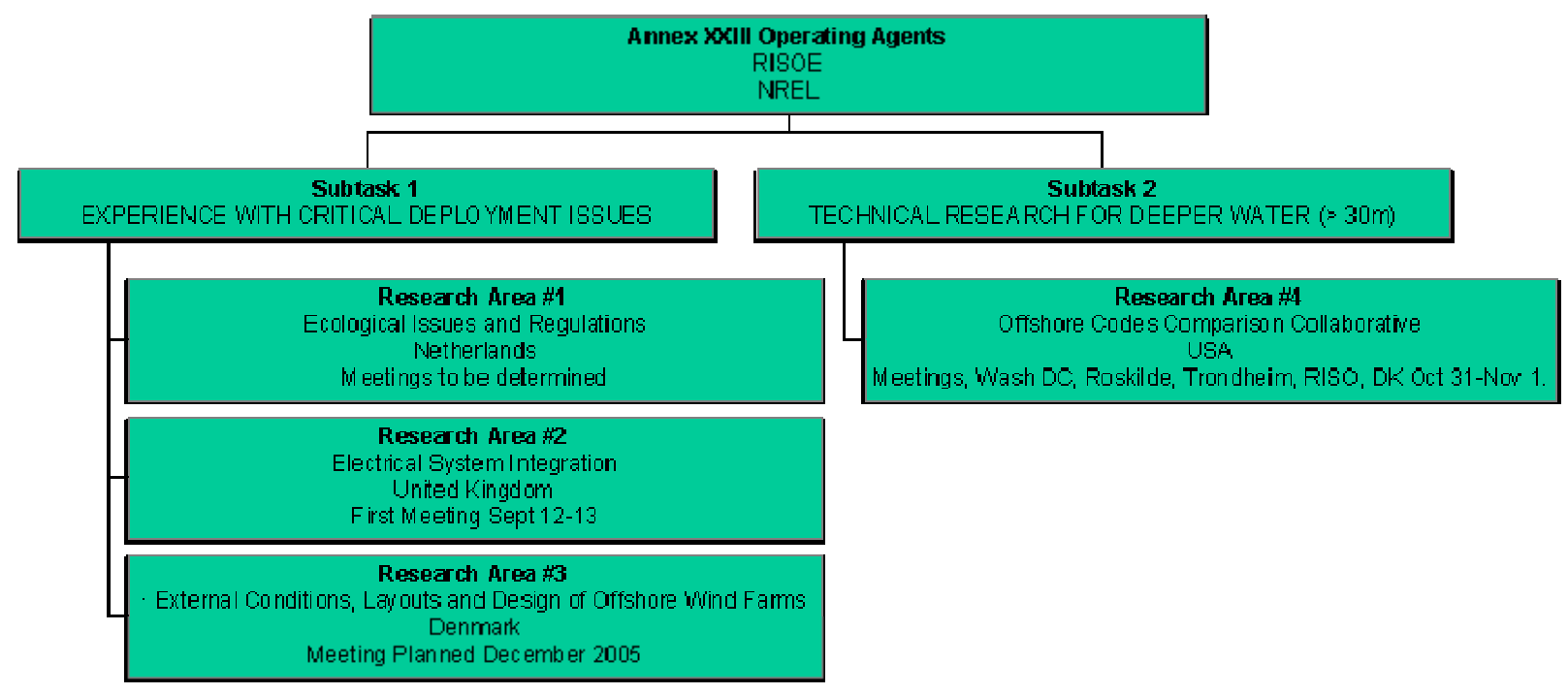

Figure 2 - Annex XXIII Organizational Flow Chart

The stated objectives of this annex are:

a) To conduct $R \& D$ activities of common interest relating to wind turbine facilities operating in offshore environments in order to reduce costs and uncertainties.

b) To identify a number of joint research tasks among interested countries based upon the broad range of issues identified at the Technical Experts Meeting \#43 on Critical Issues Regarding Offshore Technology and Deployment.

c) To organize several workshops on critical research areas relating to offshore wind deployment issues, including technical research on deeper water structures. The goal of the workshops is to identify R\&D gaps in various research areas that are of interest to participating countries, publish proceedings, and identify specific joint research areas needing further investigation

d) To identify, in year one of the Annex, interested participants and project leads for each research area, and prepare separate work programs and budgets for each collaborative research area.

\section{CURRENT STATUS}

\section{Participation}

To date, eight countries have agreed in principal to join the Annex XXIII based on participation in the Subtask 2 activities on codes and modeling, although formal commitments are still needed from many countries. Table 1 lists information by country including contracting party and participating organizations. 
Table 1 - Participating Countries

\begin{tabular}{|c|c|c|}
\hline Country & $\begin{array}{l}\text { Membership Status/ } \\
\text { Contracting Party }\end{array}$ & Organization \\
\hline United States & $\begin{array}{l}\text { Committed/US } \\
\text { Department of Energy }\end{array}$ & $\begin{array}{ll} & \text { NREL } \\
\text { - } & \text { MIT } \\
\text { - } & \text { University of Massachusetts } \\
\text { - } & \text { GE Energy }\end{array}$ \\
\hline Denmark & $\begin{array}{l}\text { Committed/RISØ National } \\
\text { Laboratory }\end{array}$ & $\begin{array}{ll}\text { - } & \text { RISØ National Laboratory } \\
\text { - } & \text { Vestas } \\
\text { - } & \text { Elsam } \\
\text { - } & \text { Carlbro }\end{array}$ \\
\hline UK & $\begin{array}{l}\text { Committed/Department of } \\
\text { Trade and Industry }\end{array}$ & $\begin{array}{l}\text { - Garrad Hassan } \\
\text { - Ceasa }\end{array}$ \\
\hline Finland & TBD & - VTT \\
\hline Norway & Enova SF - Pending & - $\quad$ NTNU-BAT \\
\hline Sweden & TBD & - Chalmers \\
\hline Netherlands & TBD & - ECN \\
\hline Japan & TBD & - MITI \\
\hline Germany & TBD & $\begin{array}{l}\text { - University of Stuttgart } \\
\text { - GE Energy }\end{array}$ \\
\hline South Korea & TBD & - Inha University \\
\hline
\end{tabular}

\section{Subtask 1-Experience With Critical Deployment Issues}

Denmark, through RIS $\varnothing$ National Laboratory, will serve as operating agent for this subtask, which will be led by Jørgen Lemming. Workshops have been planned in three research areas including:

Research Area 1: Ecological Issues and Regulations

Research Area 2: Electric System Integration

Research Area 3: External Conditions, Layouts and Design of Offshore Wind Farms.

A volunteer host country will assume the responsibility for each research area until formal research plans are adopted.

The Netherlands has agreed to host the first workshop for Research Area 1 (Ecological Issues And Regulations) but a meeting date has not yet been set. UK has agreed to host the first workshop on Grid Interconnection and the meeting was held at Manchester University 12-13 September 2005. Denmark has agreed to host the workshop for Research Area 3 (External Conditions, Layouts and Design of Offshore Wind Farms) and has set a meeting for December 2005 at RISØ National Laboratory. A significant topic dealing with Operation and Maintenance Issues was also considered a high priority topic but at this time there are no plans to hold a workshop to cover this topic. 
Research Area 1: Ecological Issues and Regulations

The areas of collaboration to be discussed at the first workshop are:

- Baseline data and research methods

- Develop methods to share baseline data and research methods for pre- and postconstruction studies.

- Impacts on the environment (assessment criteria)

○ Summarize preliminary conclusions from environmental impact assessments among nations that have offshore facilities. (This area is similar to one of the objectives of Concerted action for Offshore wind energy Deployment [COD]. This annex will collaborate with these activities whenever appropriate.)

- Evaluate potential cumulative effects to the marine ecology.

- Compare methodologies and preliminary conclusions from avian and mammal surveys.

- Permitting process

○ Evaluate streamlining of planning and approval procedures.

- Educate the regulators and facilitate interagency cooperation.

- Pre- and post-construction monitoring of operating wind facilities

- Public (stakeholder) involvement and acceptance

- Decommissioning processes and procedures.

Research Area 2: Electric System Integration

The first workshop in Research Area 2, discussed the technical options and the role of enabling technologies in achieving reliable design of offshore connections. This includes the development of offshore grids for collection and transport of significant amounts of power to the shore and the integration with the onshore transmission network.

Also, cost effective integration of offshore wind generation will require the development of systematic and consistent approaches to resolving a number of technical, commercial, and regulatory issues. These include license conditions, offshore security standards, transmission charges, grid code, connection and use of system codes, all of which were included in the scope of the workshop.

Based on a number of presentations on experiences from existing offshore wind farms and the planning process, the delegates at the workshop in Manchester concluded that the following topics were the most important for further work under Annex XIII:

- Offshore wind meteorology and impact on power fluctuations and wind forecasting

- Behavior and modeling of high-voltage cable systems

- Grid Code and security standards for offshore versus onshore

- Control and communication systems of large offshore wind farms

- Technical architecture of offshore grid systems and enabling technologies.

The working title for the working groups covering the subjects is suggested to be: Connection of Offshore Wind Farms to Onshore Grids. 
Research Area 3: External Conditions, Layouts, and Design of Offshore Wind Farms

The purpose of the workshop in Research Area \#3 is to explore the key issues and highlight the topics related to the following areas:

- Exchange, validate, and evaluate wind resource data and wind maps specific to regions with high potential for wind development.

- Share databases and innovations to enhance measurement accuracy of marine buoys pertaining to long-term sea-state and MET-Ocean data.

- Exchange technical information of wave loading prediction methods and validation experience of wave loading on wind turbine structures.

- Share experience with long-term measurement techniques and instrumentation at offshore stations.

- Evaluate various turbine array configurations in large, closely spaced farms and examine critical parameters such as mutual shadow wake effects, affect on energy production, fatigue, and ultimate loading.

- Exchange technical experience with offshore forecasting to predict wind plant output.

Each of these research areas will be narrowed in scope after a discussion to identify appropriate areas for collaboration among annex participants.

\section{Subtask 2 - Offshore Wind - Technical Research For Deeper Water}

The U.S., through the DOE National Renewable Energy Laboratory, will serve as operating agent with Walt Musial leading the Annex. The first meeting for this subtask was held on October 28, 2004, following a workshop that was held in Washington D.C., to determine the research needs for deepwater offshore wind energy technology, sponsored by the USDOE Office of Wind and Hydropower Technologies.

The meeting resulted in a decision to focus the research on Research Area 4 (Coupled Turbine/Substructure Dynamic Modeling) and to hold a planning workshop to design an IEA collaborative research program at the next meeting, which was held on January 12-13, 2005, at RISØ National Laboratory. The official name of this working group is now the Offshore Code Comparison Collaboration $\left(\mathrm{OC}^{3}\right)$, which is led by Sandy Butterfield of the National Renewable Energy Laboratory.

This meeting was held as planned. There were 25 attendees who made presentations and discussed their structural dynamics codes, and code modifications to predict dynamic response of various fixed-bottom and floating systems under simultaneous wind and wave loading. There are at least six codes under development or modification for more accurate prediction of support structure load modeling. It was agreed that the scope of Research Area 4 should not specify a minimum depth for modeling offshore support structures. All participants were interested in modeling floating platforms and were very interested in participating in a code-to-code comparison. Sandy Butterfield prepared a more detailed plan for this project, which was distributed to the participants. In addition, NREL set up a website to disseminate information for the subtask. This website is only available to members. 


\section{UPCOMING ANNEX XXIII ACTIVITIES}

The following activities have been identified for the work program of the Annex in the near term:

- Workshop on Research Area 1 - Ecological Issues and Regulations to be hosted by the Netherlands in May-June 2005.

- Workshop on Research Area 2 - Electrical System Integration held at Manchester University in the UK, 12-13 September 2005.

- Workshop on combined Research Area 3 - External Conditions, Layouts and Design of Offshore Wind Farms to be held at RISØ National Laboratory on 12-13 December 2005.

- Workshop on Research Area 4 - Offshore Code Comparison Collaboration $\left(\mathrm{OC}^{3}\right)$ to be held at RISØ National Laboratory on October 31-November 1, 2005.

\section{REFERENCES}

1. Web site for the European Wind Energy Association accessed May 19, 2004. http://www.ewea.org/

2. Web site for offshore wind energy accessed Sept 1, 2005:

http://www.offshorewindenergy.org/

3. Siegfriedsen, Lehnhoff, \& Prehn aerodyn Engineering, GmbH, Conference Proceedings of Offshore Wind Energy in the Mediterranean and other European Seas, Naples, Italy April 10-12, 2003.

4. Elliott, D.L.; Holladay, C.G.; Barchet, W.R. ; Foote, H.P.; and Sandusky, W.F. Wind Energy Resource Atlas of the United States, Solar Energy Research Institute, Golden Colorado, USA, 1987. Website: http://rredc.nrel.gov/wind/pubs/atlas/

5. Musial,W.D.; Butterfield, S, "Future For Offshore Wind Energy In The United States" Proceedings EnergyOcean 2004, W. Palm Beach, FL, June 2004. 


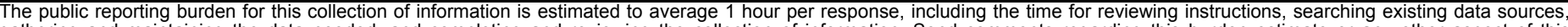

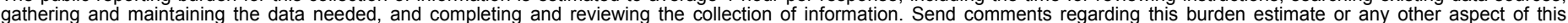

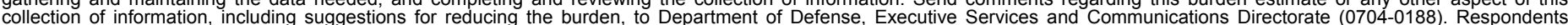

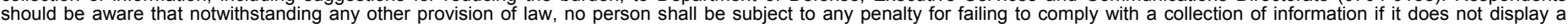

chould be aware that notwithstang

PLEASE DO NOT RETURN YOUR FORM TO THE ABOVE ORGANIZATION.

\begin{tabular}{l|l|l|l} 
1. REPORT DATE $(D D-M M-Y Y Y Y)$ & 2. & REPORT TYPE & 3. DATES COVERED (FrOm - TO)
\end{tabular}

November 2005

Conference paper

4. TITLE AND SUBTITLE

International Collaboration on Offshore Wind Energy Under IEA Annex XXIII

6. AUTHOR(S)

W. Musial, S. Butterfield, and J. Lemming 5a. CONTRACT NUMBER

DE-AC36-99-G010337

5b. GRANT NUMBER

5c. PROGRAM ELEMENT NUMBER

5d. PROJECT NUMBER

NREL/CP-500-38748

5e. TASK NUMBER

WER5.3301

5f. WORK UNIT NUMBER

7. PERFORMING ORGANIZATION NAME(S) AND ADDRESS(ES)

National Renewable Energy Laboratory

1617 Cole Blvd.

Golden, CO 80401-3393

9. SPONSORING/MONITORING AGENCY NAME(S) AND ADDRESS(ES)

10. SPONSOR/MONITOR'S ACRONYM(S)

NREL

11. SPONSORING/MONITORING AGENCY REPORT NUMBER

12. DISTRIBUTION AVAILABILITY STATEMENT

National Technical Information Service

U.S. Department of Commerce

5285 Port Royal Road

Springfield, VA 22161

13. SUPPLEMENTARY NOTES

14. ABSTRACT (Maximum 200 Words)

This paper defines the purpose of IEA Annex XXIII, the International Collaboration on Offshore Wind Energy. This international collaboration through the International Energy Agency (IEA) is an efficient forum from which to advance the technical and environmental experiences collected from existing offshore wind energy projects, as well as the research necessary to advance future technology for deep-water wind energy technology.

15. SUBJECT TERMS

offshore wind energy; International Energy Agency; NREL; Copenhagen

\begin{tabular}{|c|c|c|}
\hline $\begin{array}{l}\text { a. REPORT } \\
\text { Unclassified }\end{array}$ & $\begin{array}{l}\text { b. ABSTRACT } \\
\text { Unclassified }\end{array}$ & $\begin{array}{l}\text { c. THIS PAGE } \\
\text { Unclassified }\end{array}$ \\
\hline
\end{tabular}

\begin{tabular}{l|l} 
17. LIMITATION \\
OF ABSTRACT \\
UL
\end{tabular}

19a. NAME OF RESPONSIBLE PERSON

19b. TELEPHONE NUMBER (Include area code) 